\title{
Building the corporate image of Grand Dafam Rohan Syariah Hotel through the use of Instagram
}

\author{
Budi Setiawan \\ Magister of Communication Science, Universitas Pembangunan Nasional Veteran Yogyakarta, \\ Indonesia \\ Corresponding author: budi.com10@gmail.com
}

\author{
Article History \\ Received : 20/09/2021 \\ Revised : 30/11/2021 \\ Accepted : 15/11/2021 \\ Published : 31/12/2021
}

\begin{abstract}
Social media can be a solution for companies in branding their products. One argument is that social media can generate engagement around a brand, create a community, and serve as a customer support channel. Social media helps businesses to interact with a diverse range of stakeholders. The purpose of this study was to examine the role of the social media platform Instagram in shaping the corporate image of a hotel in Yogyakarta, Indonesia. The study used a descriptive qualitative method, with data collection tools including interviews, observations, and a library study. The research shows that Grand Dafam Rohan Syariah uses a strategy to promote its hotel by utilizing social media Instagram in carrying out its promotional activities. It used Instagram to form an image by introducing symbols and programs. The hotel's social media Instagram communicates the brand message and builds people's perceptions after seeing the postings on its Instagram accounts. However, as a new hotel, it takes time to achieve what the company expects. Thus, consistency is the key to the Grand Dafam Rohan hotel realizing its goals. Besides, there are other strategies that management should do to support all image-building programs.
\end{abstract}

Keywords: instagram, corporate image, social media

\section{Introduction}

Managing a company's reputation through communication activities has a significant impact on a company (Gray \& Balmer, 1998). The purpose of communication is to build a reputation that positively impacts the company through a sold product, either the brand management process or image branding. The brand is part of the company's identity with a selling value and is essential to be communicated to the public (Melewar et al., 2006). Corporate identity is how the company thinks about itself and how people can see it generate selling value as a differentiator from other companies (Melewar \& Karaosmanoglu, 2006). Aspects of identity can be demonstrated through corporate culture and visually depicted in slogans, logos, brands, and various corporate characters. 
Then the identity can convey to the public an impression of who and how the business is, indicating that it must be communicated to impact the company's reputation favorably. When it comes to identification, three factors contribute to reputation formation (Lange et al., 2011). First, let us examine what others have to say about the company. Second, the company's mission. Thirdly, the corporation makes a statement about itself. It is possible to understand these three aspects by recognizing actions that affect all forms of business communication with stakeholders, both primary and secondary. Image is a person's feeling or belief towards an organization (Lievens, 2018). In other words, the company's reputation is an evaluation (respect, appreciation, and appraisal) of the organization's image from the public. Corporate identity is the symbols (such as logos and color schemes) that organizations use to identify with society. Finally, corporate image is the overall impression (feelings and beliefs) of an entity (organization, country, or a particular brand) in the public's minds.

The thing that is the main focus in identity and a company asset is the brand. It is said to be an asset because the brand has a selling value for its products that differentiate from the products produced by one company to another. Brands are essential because they aim to make it easier for the public, especially consumers, to choose the product. Because of its relation to reputation takes a long time to manage a brand to become more recognized. The importance of a reputation is a sign of the existence and strength of establishing a company, especially in the era of industrial competition. A strong positive reputation among stakeholders across multiple categories will result in a solid positive reputation for the company overall (Eccles et al., 2007). In the era of technology, companies have to be more creative and understand how to use technology to improve the company's reputation. Competition in the business field: companies are facing an image war. Companies are competing to compete to publish their respective product brands.

Jefkins (Jefkins, 2018) divides the image into four categories concerning the image of the organization or company. First, the shadow image (mirror image) is held by those within an organization or company regarding how outsiders view the organization or firm. Second, the dominant image (present image) is the picture of external parties associated with the organization or corporation. Thirdly, the business or organization wants the anticipated image (wish image). The expected image is not the actual image but the better or more pleasing one. Third, the Image of the company or the Image of the institution (corporate image) is the image of an organization as a whole formed from various factors. Fourth, multiple images, namely images that arise as a result of a company or organization having many units or members. Each unit or member has different behavior and characteristics so that without realizing it, each member will bring up an image that is not 
necessarily the same as the image of the organization or company in general. As a result, the image of the organization will be as much as the number of employees it has.

The era of communication technology presents significant challenges for businesses. In this situation, businesses can employ communication technology as a catalyst for change or even as a means of annihilation. Additionally, communication technologies may help businesses brand their products. This means that utilizing communication technology will be easier, faster, and more efficient in forming the image. Along with its development, social media has emerged as a communication tool that corporations can use. Social media enables people to interact freely and provides marketers with many channels for reaching and engaging with consumers (Appel et al., 2020). Popular social media include Facebook, Instagram, Whatsapp, Twitter, and others.

Arguably, studies on image development using social media are still infrequent. The majority of studies on social media and image building have focused on businesses' interaction with and strategic approach to brand-building via social media (Cawsey \& Rowley, 2016) and how organizations Kenya build their corporate image, and how consumers respond and behave towards it (Amegbe et al., 2017). As a result, there is a dearth of research on social media and image building in Indonesia. It is this gap this study attempted to look at.

Promotional activities and the dissemination of firm information contribute to developing the company's image. One of them is Grand Dafam Hotel Syariah Hotel, a hotel that carries the concept of Sharia is also inseparable from activities to build an image using Instagram media. They realized this activity in the form of company promotions on Instagram. A unique segmentation and its own rules make this hotel's position different from other conventional hotels. Instagram represents the company's image as part of its strategy to build its reputation. So in this study, the author examined the strategy used by Grand Dafam Rohan Syariah to build a company image on Instagram social media. The research problem is how to build the corporate Image of Grand Dafam Syariah Hotel by utilizing social media Instagram.

\section{Method}

The purpose of this study was to look at how the Grand Daffam Rohan Hotel in Yogyakarta used Instagram social media as part of its communication strategy in building a positive image among its stakeholders. This research included a variety of data collection procedures, including in-depth interviews, participatory observation, reflective field notes, texts, images, photographs, and interactions. Thus, in-depth interviews with the hotel management and customers were necessary to understand better the use of Instagram in building the hotel's image. 
The researcher classified, tagged, and analyzed all available data concerning data analysis. The results would later serve as the foundation for organizing and reporting study findings.

\section{Discussion}

The advent of Internet-based social media platforms has enabled one individual to engage with hundreds, if not thousands, of other people regarding items and the businesses they offer. As a result, the market impact of consumer-to-consumer communications has been dramatically amplified (Mangold \& Faulds, 2009). Consumers create various social media accounts to obtain information and make purchasing decisions. Consumers' perceptions are more confident in sources of information on social media services through their community of friends than information through print, TV, and radio media. Mangold and Faulds (2009) state that social media services show the role of 2 interconnections, namely, firstly, social media enables companies to communicate with their consumers. Second, it facilitates between consumers to be able to communicate. In conventional marketing, consumers will talk to seven to ten consumers. Companies can talk to millions of consumers quickly on social media. Social media is an effective tool in creating viral marketing and word of mouth today.

As a new hotel in Yogyakarta, Grand Dafam Rohan Syariah is one of the 4-star hotels in Yogyakarta. The hotel, part of the Dafam hotel group, is located in the Banguntapan area of Bantul Regency with a strategic location close to Yogyakarta and Sleman Regency. The hotel provides an alternate place with the concept of premium hotel style. In addition, this hotel is one of several hotels that carry the concept of Sharia. The concept of Sharia itself has special rules according to Islamic law. By carrying out this concept, it becomes a challenge for companies to build an image and position it for specific segments. This means that as a new company, of course, Grand Dafam Rohan Syariah makes strategic efforts to promote or introduce its hotel so that people will know about the hotel. A strategy is a plan meant for proper action, a guideline for dealing with a situation. According to this definition, strategies possess two critical characteristics: they are constructed prior to executing actions and are developed intentionally and purposefully (Mintzberg, 1987). A different strategy, deliberately choosing a different set of activities to produce a unique mix of values. Choose to perform activities differently from competitors.

Positioning as a hotel with a unique segmentation makes the company carry out a strategy to build its image. Image is a collection of meanings from recognized objects, and people can describe, remember, and relate to these objects. The image reflects how the public views an organization (Gioia et al., 2000). A good corporate image cannot be bought but obtained by companies with a good 
reputation. Anggoro (2001) said that a company with a good reputation generally has six things: 1) Good relations with community leaders, 2). Positive relationship with local government, 3). Better crisis risk, 4). A sense of pride within the organization and among the target audience, 5). Mutual understanding between the target audience, both internal and external, 6). Finally, increase the loyalty of the company's staff.

Dafam Group has two different types of hotel concepts, conventional and Sharia hotel concepts. Being one of the big hotels has made the Dafam brand known before. The Dafam brand is still very attached to conventional Dafam hotels. Of course, this is an advantage in promoting the hotel. In Yogyakarta, competition in the hotel business is a challenge for companies, competing with competitors engaged in the same field to fight for market share. Hotels compete to attract consumers in various ways, apart from being a well-known brand. Determining the right strategy is also a determinant of the hotel's future. Dafam has a new business sector: opening a hotel with a Sharia concept. This concept is unique due to several rules, such as if staying overnight is only allowed by a legal husband and wife.

Being a newcomer is undoubtedly a challenge to bring up a brand known to the public. Having the name grand Dafam Rohan, this hotel dares to be different, meaning that this hotel carries out a differentiation strategy that can differentiate us from competitors to look different. The difference here is different or not the same as competitors, but it can also benefit consumers. Being different is a strategy that is widely applied today and is a strategy that is quite effective in winning the competition. A company can carry out a differentiation strategy by creating a perception of a particular value in its consumers and becoming a product/service considered unique by consumers. Consumers want to provide more value, such as superior performance, innovation, service, and a superior brand image.

Grand Dafam Rohan Syariah uses a strategy to promote its hotel by utilizing social media Instagram in carrying out its promotional activities. Efforts to form a corporate image using Instagram have effective and efficient effects and results. Using Instagram as a commercial activity under new media theory explains that social media is a new medium for social interaction and social integration. This means that as a new media, it can be used even though it is not directly face-to-face in interaction but allows two-way communication with social media. As applied by Grand Dafam, Rohan Syariah chose to use Instagram. All company activities are uploaded and informed on Grand Dafam Rohan Jogja's Instagram. The information is about hotels, hotel discount promos, food \& beverage, and hotel visitor information. 
When observing the Grand Dafam Rohan Syariah hotel's Instagram, it can be observed that every post or upload of the content material will look the same and uniform. The meaning is the same, and uniform here is about the content and appearance. The content in question is that every upload of promotional material always includes a caption or description of the words Grand Dafam Rohan Jogja, Luxurious, Experience, Meets, Style. This hotel represents itself to people who see its character with this tagline. This hotel tries to build an image of a luxury and majestic hotel, providing an exciting experience, comfortable holding meetings, and presenting a different style. The impression that the hotel wants to build is the image conveyed to the public.

Judging from the luxurious, luxurious, and majestic impression can be seen from the shape of the hotel building and the interior and exterior appearance. From the promo post content on Instagram when it displays the shape of the hotel building, especially the facilities using gray-black and white, this gives an exclusive and classy impression. The choice of color does not have a particular reason, according to the image to be built. Rules for the use of other colors have also been regulated by the management so that it cannot be arbitrary if the management is going to post something on the hotel's Instagram. Using the same type of display, framing photos with templates also has a unique feature and character to convey. In every posting of information in photos, a frame is always given to give a strong impression. The selection of fonts and colors is highly considered by management to be consistent with these rules.

Then the experience tagline gives the impression that the hotel has many excellent facilities if guests staying at the hotel will have much experience. This means that this hotel represents itself as different from other hotels. Furthermore, the hotel provides comfortable conditions regarding meets when holding a meeting here. It means that representing comfort is the main factor in providing services and is primarily pleasing to visitors. Moreover, the last thing is the style, different from other hotels, and the representation is that with the concept of Sharia, they try to make this style their strength in shaping their image. As a result, Instagram is being utilized for advertising and establishing a solid corporate image around the Sharia hotel concept.

The utilization of social media services such as Instagram can provide a platform to connect companies with consumers and consumers with consumers who talk about products. Consumers from various circles can provide comments regarding the use of the product, which can later be commented on by other companies or consumers, which can cause viral marketing effects. The advantage of social media services is that it provides a two-way communication space between consumers-companies and consumers-consumers. This two-way communication enables consumers to participate, 
collaborate and interact, which in essence, consumers are no more extended objects but become subjects. Of course, this will affect viral marketing, brand loyalty, word of mouth, and crowdsourcing.

Described in the representation theory, one of the advantages of Mitchell's model is that it emphasizes communication, which is suitable for the study of images, which may be created to communicate, or to express the feelings of the creator, or to elicit an emotional (intended) response from the viewer (Kenney, 2004). This means that if we discuss the Grand Dafam Rohan Syariah Hotel by using Instagram to form an image, the company provides a symbol, expresses what it intends to build, and builds other people's perceptions after seeing the results of postings on their Instagram accounts. This uses an image that forms the company's image but raises opinions for those who see Instagram. However, as a new hotel, it takes time to achieve what the company expects. So the strategy is more explicitly talking about the built meaning on Instagram, which aims to build an image. So consistency is the key to the Grand Dafam Rohan hotel in realizing its goals. Besides, there are other strategies that management should do to support all image-building programs.

\section{Conclusion}

Image is a perceived picture of a company by its constituents. The depiction of the image is supported by the identities that are owned and projected by the company. A set of images formed will help the company build an excellent reputation to achieve company goals. Grand Dafam Rohan chose to be different from other hotels as a new hotel. With the Sharia concept, it has positioned itself in a unique segmentation. This condition is advantageous because there is not much competition in Yogyakarta for this segmentation. To build a corporate image, this hotel uses a social media strategy to inform all hotel activities and provide characteristics built by the company.

The company places luxury, experience, meets, style as their main strength. So the company tries to represent the hotel according to the tagline. So that the public will recognize the Grand Dafam Rohan hotel as a luxurious, majestic, and exclusive hotel. This is following the company's objectives to implement the strategy consistently. This can be seen from the pattern of their Instagram content, directly and the same way using a particular template that represents the company and choosing grayblack and white to add to the exclusive impression. So that one of these strategies is still used to be part of the company's other strategies.

\section{References}

Amegbe, H., Owino, J. O., \& Kerubo, O. L. (2017). Behavioural Responses to Corporate Image Building Through Social Media Advertising: A Study Among Nairobi Students -. https://journals.sagepub.com/doi/abs/10.1177/0973258617725607 
Anggoro, M. L. (2001). Teori Dan Profesi Kehumasan: Serta Aplikasinya di Indonesia. //library.fis.uny.ac.id\%2Fopac\%2Findex.php\%3Fp\%3Dshow_detail\%26id\%3D2033

Appel, G., Grewal, L., Hadi, R., \& Stephen, A. T. (2020). The future of social media in marketing. Journal of the Academy of Marketing Science, 48(1), 79-95. https://doi.org/10.1007/s11747019-00695-1

Cawsey, T., \& Rowley, J. (2016). Social media brand building strategies in B2B companies. Marketing Intelligence \& Planning, 34(6), 754-776. https://doi.org/10.1108/MIP-04-20150079

Eccles, R., Newquist, S. C., \& Schatz, R. (2007). Reputation and Its Risks. https://hbr.org/2007/02/reputation-and-its-risks

Gioia, D. A., Schultz, M., \& Corley, K. G. (2000). Organizational Identity, Image, and Adaptive Instability. The Academy of Management Review, 25(1), 63-81. https://doi.org/10.2307/259263

Gray, E. R., \& Balmer, J. M. T. (1998). Managing Corporate Image and Corporate Reputation. Long Range Planning, 31(5), 695-702. https://doi.org/10.1016/S0024-6301(98)00074-0

Kenney, K. (2004). Representation Theory. https://www.taylorfrancis.com/chapters/edit/10.4324/9781410611581-14/representationtheory-keith-kenney

Lange, D., Lee, P. M., \& Dai, Y. (2011). Organizational Reputation: A Review. Journal of Management, 37(1), 153-184. https://doi.org/10.1177/0149206310390963

Lievens, F. (2018). The SAGE Encyclopedia of Industrial and Organizational Psychology, 2 nd edition Organizational Image. https://www.semanticscholar.org/paper/The-SAGEEncyclopedia-of-Industrial-and-PsychologyLievens/512826a47ff3da8f5e5f04a4c26faf6d5f2a54d4

Mangold, W. G., \& Faulds, D. J. (2009). Social media: The new hybrid element of the promotion mix. Business Horizons, 52(4), 357-365. https://doi.org/10.1016/j.bushor.2009.03.002

Melewar, T. C., Bassett, K., \& Simões, C. (2006). The role of communication and visual identity in modern organisations. Corporate Communications: An International Journal, 11(2), 138147. https://doi.org/10.1108/13563280610661679

Melewar, T. C., \& Karaosmanoglu, E. (2006). Seven dimensions of corporate identity: A categorisation from the practitioners' perspectives. European Journal of Marketing, 40(7/8), 846-869. https://doi.org/10.1108/03090560610670025

Mintzberg, H. (1987). The Strategy Concept I: Five Ps for Strategy. California Management Review, 30(1), 11-24. https://doi.org/10.2307/41165263 